\title{
Grape harvest dates as a proxy for Swiss April to August temperature reconstructions back to AD 1480
}

\author{
Nicole Meier, ${ }^{1}$ This Rutishauser, ${ }^{1}$ Christian Pfister, ${ }^{2,3}$ Heinz Wanner, ${ }^{1,3}$ \\ and Jürg Luterbacher ${ }^{1,3}$ \\ Received 19 July 2007; revised 23 August 2007; accepted 4 September 2007; published 24 October 2007.
}

[1] We present an annually resolved record of grape harvest dates for Switzerland. The strong negative relationship between grape harvest dates and AprilAugust temperatures allowed a new reconstruction, with associated uncertainties, to be derived back to 1480 . Calibration (1928-1979) was performed with monthly data from the Basel and Geneva stations and verified over 1980-2006. Twelve days of grape harvest difference correspond to around $1{ }^{\circ} \mathrm{C}$ April-August temperature difference. Periods cooler (late grape harvest dates) than the 1961-1990 mean are reconstructed during the 17 th century and at the beginning of the 19th century. Warmer conditions were experienced in the early 18 th century and during the recent decades, in agreement with grape harvest temperature reconstructions from France and other independent temperature estimates. On decadal (annual) time-scales the earliest harvests were in the $1580 \mathrm{~s}$ (2003) and the latest vintages in the 1740s (1816). Large tropical volcanic eruptions led to significantly later grape harvest dates (cooling) one to two years after the event. Citation: Meier, N., T. Rutishauser, C. Pfister, H. Wanner, and J. Luterbacher (2007), Grape harvest dates as a proxy for Swiss April to August temperature reconstructions back to AD 1480, Geophys. Res. Lett., 34, L20705, doi:10.1029/2007GL031381.

\section{Introduction}

[2] Grape harvest dates are a precisely dated documentary climate proxy archive extending from the present to medieval times [Le Roy Ladurie, 1971; Pfister, 1999]. Grape growth and ripening closely depend upon the temperature integral over the whole vegetation period and relate to the harvest date at the end of the growing season. According to reasoning provided by Pfister [1999], Jones [2003], Chuine et al. [2004], and Le Roy Ladurie [2005], most of the climatic influence takes place before the phenological stage of veraison in July or August [Mullins, 1992; Meier, 2007]. After this stage, berry growth ceases and sugar accumulation and colour changing begin. $\mathrm{C}$ Schleip et al. (Impact of climate change on summer and spring phenology in Switzerland in the last 250 years, submitted to Journal of Geophysical Research, 2007, here-

\footnotetext{
${ }^{1}$ National Centre of Competence in Research on Climate (NCCR) and Institute of Geography, University of Bern, Bern, Switzerland.

${ }^{2}$ National Centre of Competence in Research on Climate (NCCR) and Institute of History, University of Bern, Bern, Switzerland.

${ }^{3}$ Oeschger Centre for Climate Change Research, University of Bern, Bern, Switzerland.
}

Copyright 2007 by the American Geophysical Union. 0094-8276/07/2007GL031381 inafter referred to as Schleip et al., submitted manuscript, 2007) find a significant contribution effect of May and June temperatures. In accordance to Alleweldt [1967], Schleip et al. (submitted manuscript, 2007) state that the development of the grapevine and, thus, the archived temperature signal is closed in August. Thus the main climatic signal integrates late spring to mid-summer temperatures. Documentary records of grape harvest dates have been previously used to reconstruct temperature [Le Roy Ladurie, 1983; Le Roy Ladurie et al., 2006; Pfister, 1992, 1999] and North Atlantic Oscillation Index (NAOI) [Souriau and Yiou, 2001]. In Burgundy, they were used to reconstruct April-August temperatures from 1370 to 2003 using a process-based phenology model developed for the Pinot Noir grape variety [Chuine et al., 2004]. Anomalously high temperatures, similar to those of the 1990s, occur several times earlier in this record [Chuine et al., 2004]. Menzel [2005] used the same grape harvest data of Le Roy Ladurie [1983] to derive a mean April-August temperature response reconstruction applying linear regression analysis. Guiot et al. [2005] used grape harvest data in a multiproxy approach to reconstruct millennium long western European summer temperature. In this study, grape harvest data for more than half of a millennium from Switzerland are used as a proxy for a statistical reconstruction of April to August temperature anomalies. The new reconstruction is compared to independent temperature estimates from Europe.

\section{Data}

[3] Grape harvest date observations for Switzerland were found for the 1480-2006 period (Figure 1). In total, 1435 dates from 15 locations in the Swiss Plateau region and north-western Switzerland were collected [Pfister and Dietrich-Felber, 2006; Landwirtschaftsdirektion, 2007]. The data possess some temporal gaps, between 1481 and 1600, and at 1876, between 1879 and 1884, and in 1927. Mainly before 1600, gaps appear primarily due to missing years of observation. Between 1879 and 1884 gaps are the consequence of severe, wide spread grape harvest diseases [Mullins, 1992], such as the phylloxera which also heavily affected the vineyards in the Swiss Plateau region. April to August monthly temperatures from Geneva (starting in 1753) and Basel (starting in 1755 [Schüepp, 1961]; homogenized after 1864 by Begert et al. [2005]) were averaged and served as the predictand for the new statistically reconstructed temperature series for western Switzerland back to 1480 . For comparison with the Swiss grape harvest data the updated Burgundy grape harvest data set from Le Roy Ladurie et al. [2006] was used. In addition, the temperature reconstruction is related to tree-ring based 


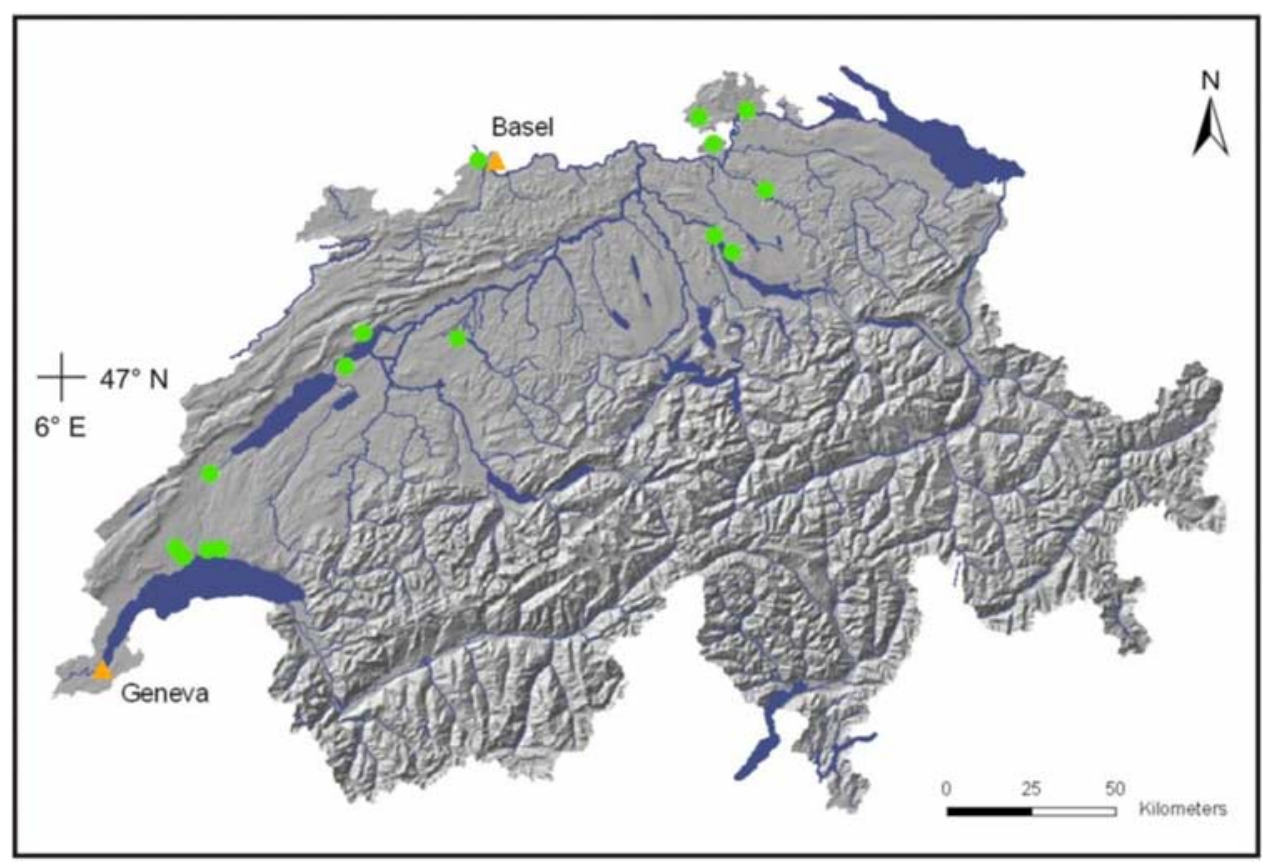

Figure 1. Topographical map of Switzerland showing the sites of grape harvest observations in the Swiss Plateau region (green dots) and temperature stations used for calibration (orange triangles).

temperature estimates from the Swiss Alps [Büntgen et al., 2006], and multi-proxy, monthly temperature reconstructions for the larger Alpine area [Casty et al., 2005] and European land regions [Luterbacher et al., 2004; Xoplaki et al., 2005]. Table 1 contains information related to the different grape harvest proxy series and temperature reconstructions used in this study.

\section{Methods}

[4] The Swiss grape harvest series was derived as the median value of the available records per year following the approach of Chuine et al. [2004]. Similar results were obtained in tests with arithmetic mean and mixed linear modelling (MLM) [Schaber and Badeck, 2002] approaches with small differences between median and mean/MLM at decadal time scales throughout the record (not shown). For calculations, calendar dates were transformed in days of the year (DoY) starting with January 1st. Any gaps in the time series were not filled to accurately represent the underlying data. Decadal variability was analyzed by applying a 10 -year low-pass filter. The median time series was further used as predictor for the Swiss Plateau region temperature reconstruction based on linear regression. 1928-1979 was used as the calibration period, and the record was verified over the 1980-2006 period. We tested different combinations of months and seasons and found April-August to yield the most stable and highest correlation with grape harvest dates (not shown). For the final April-August reconstruction back to 1480 the whole period from 1928-2006 was used.

Table 1. Compilation of information to the different grape harvest proxy series and temperature reconstructions used in this study. ${ }^{\mathrm{a}}$ All correlations are statistically significant at the $99.9 \%$ level.

\begin{tabular}{|c|c|c|c|c|c|c|c|}
\hline Series & $\begin{array}{c}\text { Grape } \\
\text { Harvest } \\
\text { Swiss } \\
\text { Plateau, } \\
\text { [This } \\
\text { Study] } \\
\end{array}$ & $\begin{array}{c}\text { Grape } \\
\text { Harvest } \\
\text { Burgundy } \\
\text { [Chuine et } \\
\text { al., 2004] }\end{array}$ & $\begin{array}{c}\text { Grape } \\
\text { Harvest } \\
\text { Burgundy } \\
\text { [Le Roy } \\
\text { Ladurie et } \\
\text { al., 2006] }\end{array}$ & $\begin{array}{c}\text { Average } \\
\text { Temperature } \\
\text { of Basel } \\
\text { and } \\
\text { Geneva, } \\
\text { Switzerland }\end{array}$ & $\begin{array}{c}\text { Tree Rings, } \\
\text { Alps } \\
\text { [Büntgen et } \\
\text { al., 2006] }\end{array}$ & $\begin{array}{c}\text { Multiproxy, } \\
\text { Alps } \\
\text { [Casty et } \\
\text { al., } \\
2005]\end{array}$ & $\begin{array}{c}\text { Multiproxy, } \\
\text { Europe } \\
\text { [Luterbacher } \\
\text { et al., 2004; } \\
\text { Xoplaki et al., 2005] }\end{array}$ \\
\hline Time range & $1480-2006$ & $1480-2003$ & $1480-2003$ & $1755-2005$ & $1480-2004$ & $1659-2000$ & $1659-2003$ \\
\hline $\mathrm{r}$ & - & 0.71 & 0.68 & 0.79 & 0.36 & 0.65 & 0.40 \\
\hline $\begin{array}{l}\text { TT-Mean } \\
\quad 1780-1830 \\
\quad(\text { wrt } 61-90)\end{array}$ & -0.22 & -0.39 & - & -0.15 & -0.63 & 0.52 & 0.16 \\
\hline $\begin{array}{l}\text { TT-SD } \\
\quad 1780-1830 \\
(\text { wrt } 61-90)\end{array}$ & 0.79 & 0.94 & - & 0.85 & 0.98 & 0.74 & 0.42 \\
\hline $\begin{array}{l}\text { Reconstruction } \\
\text { Type }\end{array}$ & $\begin{array}{c}\text { linear regression } \\
\text { model }\end{array}$ & $\begin{array}{l}\text { growth } \\
\text { model }\end{array}$ & - & - & $\begin{array}{l}\text { wavelength } \\
\text { dependent } \\
\text { regression }\end{array}$ & $\begin{array}{l}\text { PCA multiple } \\
\text { regression }\end{array}$ & $\begin{array}{l}\text { PCA multiple } \\
\text { regression }\end{array}$ \\
\hline Calibration & $1928-1979$ & $1964-1981$ & - & - & $1818-1910$ & $1901-1960$ & $1901-1960$ \\
\hline Verification & $1980-2006$ & $1982-2001$ & - & - & $1911-2003$ & $1961-1995$ & $1961-1995$ \\
\hline
\end{tabular}

${ }^{\text {a}}$ Correlations (r) are calculated over the common period. TT-Mean represents the mean temperature and TT-SD the standard deviation over the period $1780-1830$. 


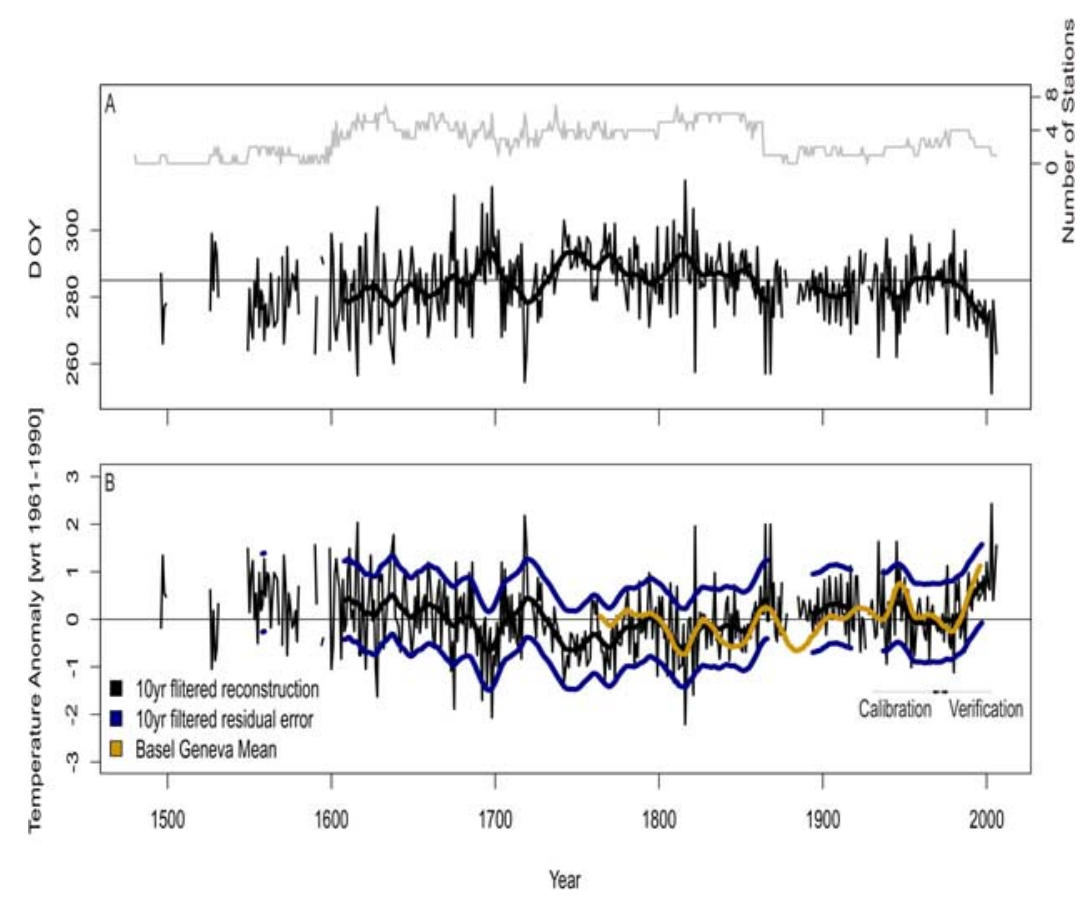

Figure 2. (a) Observed grape harvest dates with a 10-year Gaussian filter (bold black line) for the Swiss Plateau region (left scale). The horizontal line indicates the long term average of 12 October (Julian Day 285) of the reference period 1961-1990. The numbers of observation sites (= number of stations) is shown in the grey curve (right scale). (b) Annual and 10-year filtered (black line) April-August temperature anomalies (with respect to 1961-1990) reconstructed from Swiss grape harvest dates. The filtered residual errors are presented in blue. Average temperature anomalies of Basel and Geneva are shown with the yellow line.

Systematic analysis of shared variance $\left(\mathrm{R}^{2}\right)$ of the regression models and reduction of error (RE) [e.g., Cook et al., 1994] scores for different calibration and verification periods in the 18th, 19th and the 20th century were also tested [Meier, 2007]. Moving Pearson correlations after 1550 (gaps in the earlier Swiss grape harvest data) were calculated to assess temporal evolution of coherence of different temperature measurements and series. Gershunov et al. [2001] pointed out that autocorrelations have to be accounted for when calculating significance thresholds for running correlation coefficients. Therefore, we estimated a conservative estimate 95\% confidence levels using MonteCarlo simulations. One thousand random time series having the same standard deviation, mean and lag-one autocorrelation coefficients as the original data are computed and then correlated [Wilks, 1995].

\section{Results and Discussion}

[5] Figure 2a shows the annually resolved time series of median grape harvest dates for the Swiss Plateau region 1480-2006. The mean date for the 1961-1990 period is 12 October (DoY 285). In general, earlier dates were experienced in the first part of the 17 th century as well as the early and late 20th century and the beginning of the 21 st century. An extended period of late grape harvest dates can be found from the late 18th to the early 19th century. At decadal time scale, the earliest harvests were in the $1580 \mathrm{~s}$ (mean DoY 273) and the latest decadal vintages in the 1740s (mean DoY 295). The earliest grape harvest was on September 8 in 2003 (DoY 251) followed by 1540 (DoY 254). Late grape harvests were for instance in 1698 and
1816 ("year without a summer"). Interestingly, the majority of very late harvests are followed after strong tropical volcanic events (see auxiliary material). ${ }^{1}$ Fischer et al. [2007] find that the direct radiative cooling effect is responsible for the continental scale summer cooling one to three years after major eruptions. This pattern of summer cooling (and drier conditions over Central Europe) of the strong tropical volcanoes seems to be remarkably robust back to 1500 [Fischer et al., 2007]. The correlation between the Swiss and the Burgundy grape harvest data [Chuine et al., 2004; Le Roy Ladurie et al., 2006] is approximately 0.7 for common years $(r=0.69$ in the 20 th century; see Table 1$)$. In Figure $2 \mathrm{~b}$ the statistically reconstructed Swiss AprilAugust mean temperatures from grape harvest dates are plotted with respect to the reference period 1961-1990. Grape harvest dates explain 79\% (57\%) of April-August mean temperature variance in the verification (calibration) period $(\mathrm{RE}=0.46)$. The final temperature reconstruction does not significantly differ if other calibration periods are applied (not shown). The reconstruction is plotted with its 10 year filtered residual errors (Figure 2b). There is a strong negative link between the grape harvest dates and Swiss April-August temperature. An earlier grape harvest of around 12 days corresponds to approximately $1{ }^{\circ} \mathrm{C}$ increase in April-August temperature. Periods warmer than the 1961-1990 mean are reconstructed between 1600 and 1670 , at the beginning of the 18 th century with a maximum in 1718 , at the end of the 18 th century, in the 1860 s to 1870 s

\footnotetext{
${ }^{1}$ Auxiliary materials are available at $\mathrm{ftp}: / / \mathrm{ftp}$.agu.org/apend/gl/ 2007GL031381.
} 


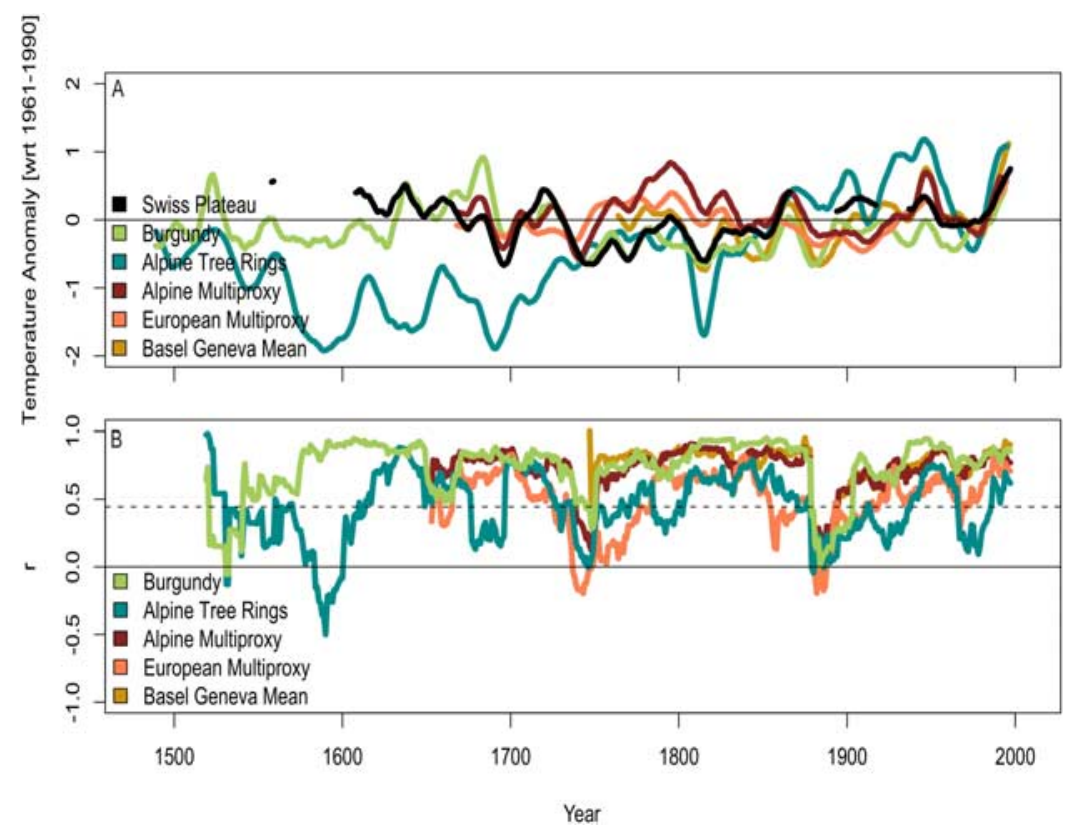

Figure 3. (a) Comparison of the Swiss temperature reconstruction based on grape harvest dates (1480-2006, black) with the Burgundy temperature reconstruction (1370-2003) [Chuine et al., 2004], Alpine June-September temperatures reconstructed from tree rings (755-2004) [Büntgen et al., 2006], Alpine April-August multiproxy temperature reconstruction based on documentary proxy evidence and early instrumental measurements (1659-2000) [Casty et al., 2005], European land area April-August multiproxy temperature reconstruction (1659-2004) [Luterbacher et al., 2004; Xoplaki et al., 2005], and measured averaged Basel and Geneva April-August mean temperatures (1755 to 2006) [Schüepp, 1961; Begert et al., 2005]. All series are decadally smoothed and with respect to the 1961-1990 period. (b) 20-year running Pearson correlation coefficients ( $r$ ) of reconstructed and measured temperature series presented in Figure 3a. Significance level derived by 1000 simulated random time series having the same mean, standard deviation and autocorrelation as the original time series according to Wilks [1995]. The dashed line represents the estimated $95 \%$ confidence level using Monte-Carlo simulations.

and at the end of the 20th century as well as at the beginning of the 21 st century. Cooler periods occurred before 1700 and furthermore at the beginning of the 19th century. The decadal temperature range, determined between the latest grape harvest decade (1740s) and the earliest ten consecutive years $(1580 \mathrm{~s})$ is of the order of $2^{\circ} \mathrm{C}$. A couple of recent studies suggest, that early warm-season most of the early instrumental temperature series including Basel and Geneva (before around the 1850s) might be subject to systematic warm biases (approximately $+0.4-0.5^{\circ} \mathrm{C}$ ) due to insufficient sheltering from direct or reflected radiation [e.g. Frank et al., 2007 and references therein; Reinhard Böhm, ZAMG, personal communication, 2007]. Consistent with this, we find no evidence of longer periods with early grape harvests in Switzerland during the 1780-1830 period in comparison to the last half of the millennium.

[6] On annual time scale, the uncertainties of reconstructed April-August temperatures are around $0.82^{\circ} \mathrm{C}$. The uncertainty ranges presented in Figure $2 \mathrm{~b}$ are based entirely on the reconstructive skill obtained during the calibration period. It is however very likely, that the earlier uncertainties are underestimated for various reasons within the documentary proxy itself. In fact, grape harvest dates are precisely documented (see above) but underlie changing viticultural traditions and other environmental influences than temperature. Lachiver [1988] investigated the institutional context of the vintage ban in his history of viticulture in France. He discovered that before the 17th century the vintage was opened on a preferential day of the week according to local tradition. This confirmed the results of a statistical analysis by Legrand [1979], who demonstrated that small variations of early vine harvest data could not be interpreted in strictly climatic terms. Moreover, Lachiver [1988] pointed to the fact that vine growing before the 17th century was dominated by motives of risk aversion. The strategy was mixed planting of early and late varieties in order to still have a minimum yield in a bad year. Later on local traditions vanished as market forces became dominant. In consequence, homogenous grape varieties were planted and cultivation was directed towards obtaining higher sugar content. Additional uncertainties include war times that attracted mercenary soldiers from farmer communities (only marginal in Switzerland). The numerical quantification of the proxy inherent uncertainty and statistical reconstruction uncertainty is very difficult [e.g., Keenan, 2007]. In addition, anomalously high September precipitations fosters diseases and irregular sugar assimilation and, thus, distort the accuracy of the harvest date. We derived 29 extremely wet September months of the past 500 years from Pfister [1999] (see auxiliary material). In summary, we believe that the calculated uncertainties are optimistic estimates due to additional uncertainties mentioned above. Figure 3a presents a comparison of the Swiss temperature reconstruction based on grape harvest dates and of other independent temperature reconstructions. Except for the Alpine tree ring summer temperature reconstruction [Büntgen et al., 2006], 
all other temperature reconstructions [Casty et al., 2005; Chuine et al., 2004; Luterbacher et al., 2004; Xoplaki et al., 2005] show approximately the same variability over the last 500 years (Table 1 and Figure 3a). The greater amplitude of the tree-ring reconstruction can be related to both scaling uncertainties/dependence upon particular statistical reconstruction approaches as well as amplitude dependence upon both the spatial and temporal scales of interest [e.g., Esper et al., 2005]. The courses of the curves are similar between $1740-1790,1810-1830,1860-1880$ and $1950-2000$. A divergence of the curves is seen mainly before 1700 , between 1790-1810, between $1830-1860$ and $1880-$ 1950. Frank et al. [2007] discuss possible reasons for the substantial divergence and the systematic and continuous undershooting of the early instrumental target data prior to $\sim 1850$ by alpine tree-ring based reconstructions. They formulate five hypotheses towards explaining this phenomenon: tree-ring detrending methods, biological persistence in the proxy time-series, instabilities and uncertainties in the tree ring growth response to given climatic parameters, reduced instrumental station availability back in time, and finally instrumental data homogeneity. According to Frank et al. [2007] the full quantification of the likelihood and magnitude of each of these factors remains a central question that cannot yet be satisfactorily addressed. Frank et al. [2007] hypothesize, however, that early instrumental data inhomogeneities related to changes in thermometer exposures seems to be the most important factor in explaining this offset for central Europe. While our grape-harvest record shows below average warmth during this instrumental period, the long-term warming trend since about 1600 in the tree-ring data is not evident in our reconstruction nor the independent multi-proxy, documentary-based or grape harvest reconstructions.

[7] The correlations between this new temperature series and the other independent reconstruction of common lengths are all statistically significant at the $95 \%$ level (Table 1). Figure $3 \mathrm{~b}$ shows the running correlations between the Swiss Plateau temperature reconstruction and independently derived summer temperature estimates from Central Europe. The strongest and stable relationship $(\mathrm{r}=0.83$ for the 1928-2003 period) is found between this temperature reconstruction and the one of the Burgundy region [Le Roy Ladurie et al., 2006]. With the other time series, a period with negative correlations is found until the middle of the 18th century. Afterwards, continuous significantly high correlations are observed. Due to missing values in Switzerland at the end of the 19th century following a wide-spread grape harvest disease, the correlations are non-significant $(p<0.05)$. From the 20th century onwards, a trend towards significant positive correlations is noticed. Running correlations indicate the uncertainties within the grape harvest date proxy series. They show abrupt changes in one record or shifts in opposite directions of both correlated records. Le Roy Ladurie and Baulant [1980] showed that the coefficients of correlation between the series varied over time. These results suggest that the relationship between temperature and the date of grape harvests is not stationary. Hence Guerreau [1995] and Keenan [2007] concluded that grape harvest dates alone are only a second class evidence for temperature reconstruction. Our analysis show, however, that there is a change in correlations between grape harvest dates and temperature but there is no general trend over time.

\section{Conclusions}

[8] Grape harvest dates are an important regional climate proxy for summer temperature as they provide one of the longest uninterrupted series without chronological uncertainties. The strong negative relationship between grape harvest dates and Swiss April-August temperature over the 1928-2006 period has been used to statistically reconstruct (with associated uncertainties) a new temperature series back to 1480 . Twelve days of difference in the grape harvest date corresponds to approximately $1{ }^{\circ} \mathrm{C}$ AprilAugust temperature difference. In agreement with recent studies, we found the earliest harvest in 2003 and the latest harvest in 1816. Large tropical volcanic eruptions over the last half millennium lead to significantly later grape harvest dates (cooling) one to two years after the event. Comparisons with independent temperature reconstructions indicate similar variability, except for the alpine tree ring reconstruction. Grape harvest dates will contribute to the understanding of possible biases in the early instrumental summer season measurements and/or tree-ring data and thus help to disentangle discrepancies between tree ring based temperature reconstructions and early instrumental data [e.g., Frank et al., 2007] in future European studies. Including grape harvest yield and sugar content observations will further reduce the uncertainty of this unique documentary proxy record.

[9] Acknowledgments. This research is supported by the Swiss National Science Foundation (project "Past, Present and Future Climate Impact on Spring and Summer Vegetation - a Phenological Approach" contract 205321-105691/1) and through its National Center of Competence in Research on Climate (NCCR-Climate), projects PALVAREX and CAPRICORN and the Oeschger Centre for Climate Change Research. We are grateful to David Frank (WSL) for discussions on various aspects of this paper, Ulf Büntgen for the tree ring data and Florian Schaffner for mapping support. The publication is financially supported by the Foundation Marchese Francesco Medici del Vascello.

\section{References}

Alleweldt, G. (1967), Der Einfluss des Klimas auf Ertrag und Mostqualität der Reben, Rebe Wein, 20, 312-317.

Begert, M., T. Schlegel, and W. Kirchhofer (2005), Homogenous temperature and precipitation series of Switzerland from 1864 to 2000, Int. J. Climatol., 25, 65-80.

Büntgen, U., D. C. Frank, D. Nievergelt, and J. Esper (2006), Summer temperature variations in the European Alps, AD 755-2004, J. Clim., 19, 5606-5623.

Casty, C., H. Wanner, J. Luterbacher, J. Esper, and R. Böhm (2005), Temperature and precipitation variability in the European Alps since 1500, Int. J. Climatol., 25, 1855-1880.

Chuine, I., P. Yiou, N. Viovy, B. Seguin, V. Daux, and E. Le Roy Ladurie (2004), Grape ripening as a past climate indicator, Nature, 432, 289-290.

Cook, E., K. Briffa, and P. D. Jones (1994), Spatial regression methods in dendroclimatology: A review and comparison of two techniques, Int. J. Climatol., 14, 379-402.

Esper, J., D. C. Frank, R. J. S. Wilson, and K. R. Briffa (2005), Effect of scaling and regression on reconstructed temperature amplitude for the past millennium, Geophys. Res. Lett., 32, L07711, doi:10.1029/2004GL021236.

Fischer, E. M., J. Luterbacher, E. Zorita, S. F. B. Tett, C. Casty, and H. Wanner (2007), European climate response to tropical volcanic eruptions over the last half millennium, Geophys. Res. Lett., 34, L05707, doi:10.1029/2006GL027992.

Frank, D., U. Büntgen, R. Böhm, M. Maugeri, and J. Esper (2007), Warmer early instrumental measurements versus colder reconstructed temperatures: Shooting at a moving target, Quat. Sci. Rev., in press. 
Gershunov, A., N. Schneider, and T. Barnett (2001), Low-frequency modulation of the ENSO Indian monsoon rainfall relationship: Signal or noise?, J. Clim., 14, 2486-2492.

Guerreau, A. (1995), Climat et Vendanges: Révisions et compléments, Hist. Mes., 10, 89-147.

Guiot, J., A. Nicault, C. Rathgeber, J. Edouard, F. Giubal, G. Pichard, and C. Till (2005), Last millennium summer temperature variations in western Europe based on proxy data, Holocene, 15, 489-500.

Jones, G. (2003), Winegrape phenology, in Tasks for Vegetation Science, vol. 39, Phenology: An Integrative Environmental Science, edited by M. Schwartz, pp. 523-539, Springer, New York.

Keenan, D. (2007), Grape harvest dates are poor indicators of summer warmth, Theor. Appl. Climatol., 87, 255-256.

Lachiver, M. (1988), Vins, Vignes et Vignerons: Histoire du Vignoble Français, Fayard, Paris.

Legrand, J.-P. (1979), Les variations climatiques en Europe Occidentale depuis le Moyen-Age, Météorologie, 6, 167-182.

Le Roy Ladurie, E. (1971), Times of Feast, Times of Famine: A History of Climate Since the Year 1000, Doubleday, New York.

Le Roy Ladurie, E. (1983), Historie du Climat Depuis l'an Mil, Camps Flammation, Paris.

Le Roy Ladurie, E. (2005), Canicule, fraîcheurs, vendages (France, XVeXIXe siègles), C. R. Biol., 328, 213-222.

Le Roy Ladurie, E., and M. Baulant (1980), Grape harvests from the fifteenth through the nineteenth centuries, J. Interdiscip. Hist., 10, $839-849$.

Le Roy Ladurie, E., V. Daux, and J. Luterbacher (2006), Le climat de Bourgogne et d'ailleurs, Hist. Econ. Soc., 3, 421-436.

Luterbacher, J., D. Dietrich, E. Xoplaki, M. Grosjean, and H. Wanner (2004), European seasonal and annual temperature variability, trends and extremes since 1500, Science, 303, 1499-1503.

Meier, N. (2007), Grape harvest dates as a proxy for Swiss April to August temperature reconstructions, M. S. thesis, Univ. of Bern, Bern. (Available at http://www.geography.unibe.ch/lenya/giub/live/research/climatology/ publications/diploma en.html.)

Menzel, A. (2005), A 500 year pheno-climatological view on the 2003 heatwave in Europe assessed by grape harvest dates, Meteorol. Z., 14, $75-77$.

Mullins, M. (1992), Biology of the Grapevine, Cambridge Univ. Press, Cambridge, U. K.

Pfister, C. (1992), Monthly Temperature and Precipitations in Central Europe 1525 - 1979: Quantifying Documentary Evidence on Weather and Its Effects, Routledge, London.

Pfister, C. (1999), Wetternachhersage: 500 Jahre Klimavariationen und Naturkatastrophen, Paul Haupt, Bern.

Pfister, C., and U. Dietrich-Felber (Eds.) (2006), EuroClimhist: A Data-Base on Past Weather and Climate in Europe and Its Human Dimension, Version 2006-02-01, www.euroclimhist.com, Univ. of Bern, Bern.

Schaber, J., and F.-W. Badeck (2002), Evaluation of methods for the combination of phenological time series and outlier detection, Tree Physiol., 22, 973-982.

Schüepp, M. (1961), Lufttemperatur, Schweiz. Meteorol. Anst., Zürich.

Souriau, A., and P. Yiou (2001), Grape harvest for checking NAO paleoreconstructions, Geophys. Res. Lett., 28, 3895-3898.

Unit of Viticulture (2007), Annual report of the Landwirtschaftsdirektion of the State of Bern, Bern.

Wilks, D. S. (1995), Statistical Methods in the Atmospheric Sciences: An Introduction, Academic, San Diego, Calif.

Xoplaki, E., J. Luterbacher, H. Paeth, D. Dietrich, N. Steiner, M. Grosjean, and H. Wanner (2005), European spring and autumn temperature variability and change of extremes over the last half millennium, Geophys. Res. Lett., 32, L15713, doi:10.1029/2005GL023424.

J. Luterbacher, N. Meier, C. Pfister, T. Rutishauser, and H. Wanner, National Centre of Competence in Research on Climate (NCCR), University of Bern, CH-3012 Bern, Switzerland. 